\title{
STABILITY ANALYSIS FOR GRAIN YIELD IN BREAD WHEAT GENOTYPES
}

\author{
Sh.A. El-Shamarka(1), M.A. AboShereif(2), I.H. Darwesh ${ }^{(1)}$, A.N. Kahali(2) \\ and Hend. H. Elfiki(2) \\ (1) Agronomy Dep., Faculty of Agric., Shibin El-Kom, Minufiya University. \\ (2) Wheat Research Department, Agriculture Research Center (ARC)
}

Received: Feb. 14, 2019

Accepted: Feb. 27, 2019

\begin{abstract}
Wheat breeders have to determine the new cultivars and lines responsive to the environmental changes for grain yield and yield components. Therefore, this study was conducted to evaluate 20 bread wheat (Triticum aestivum L) genotypes including 9 registered cultivars and 11 promising lines for their stability grown in five different locations (EL-Gemmeiza, Sakha, Nubaria, Sids and Shandaweel Agricultural Research Station) for three growing seasons (2009-2010, 2010-2011 and 2011-2012), and to select genotypes having desirable traits to be used in twenty bread wheat genotypes. Field trials were conducted in a randomized complete block design with three replications at each location. Number of spikes per square meter, number of kernels per spike, 1000-kernel weight and grain yield of the genotypes were evaluated in each location.The AMMI analysis showed that $(73.79,57.28,47.27$ and $22.51 \%)$ of the total squares were due to environmental impacts $(1.72,4.96,4.01$ and 20.37$)$ to genetic effects $(13.65,24.44,27.76$, and $32.4 \%$ ) of the effects GEI on the grain yield, the number of spikes / $\mathrm{m}^{2}$, number of kernels / spike and 1000-kernel weight, respectively.
\end{abstract}

The genetics (GEI) were divided into three axes for the analysis of the reaction components (IPCA) of the grain yield and its components.

The results showed that IPCAs were of great importance. Three IPCAs $(55.77,63.76,61.45$ and $67.38 \%$ ) represented the interaction variation of the grain yield, the number of spikes I $m$ 2, the number of kernels / spike and the weight of 1000 -grain, respectively.

The most stable genotypes were Giza 168, G18, G13, Gemmeiza11 and G10 with high yield potential. For grain yield.

The best genotypes with respect to E5 and E14 were Sids12 and Masr1. For E13, E3, E2 and E7 as well as for G20 and G 17. For E6, E1 and E15, were G11. The E4 had Sids13 and shandaweel1. E9, E11, E8 and E12 were the G12. E1, E9 and E13 were also the most distinct environments. For grain yield. The most stable genotypes were G18, G16, Masr2, G13and G20 with high production potential,

For recorded Gemmeiza 11 genotypes at environments E15, E10, E8, E3, E9, E5, E13, E4 and E12. For E6, E2, E1, E7 and E11 were Sids13. It also shows that E1 and E6 are the most distinct environments. For Number of spike/ $\mathrm{m}^{2}$

The most stable genotypes were G19, G13, G15 Sids13and G14 with high production potential for Number of kernels/spike. The best genotype namely G20 were E7, E12, E2, E8. and G10 for E1, E13, E3 and E10. For E5, E15 and E4, they were G1. For E9, E6 and E14 were Shandaweel1. It also shows that E14, E15, E5 and E4 were the most distinctive environments. for Number of kernels/spike.

The most stable genotypes were Masr2, Sids12, Sids13 G12 and G13 with high potential, The best genotypes with respect at environment number E4, E5, E7, E10, E14 and E15 were Gemmeiza11. For environment number E6 and E1were genotype number G17.At environment number E3, E19 and E13 were genotypes number G19.The best distinct environment number E1 and E9 for the 1000 kernel-weight. 
Sh. A. El-Shamarka, et al.,

Key words: Bread Wheat, Grain Yield, Ammi Stability Value

\section{INTRODUCTION}

Wheat (Triticum aestivum $L$ ) is one of the most important crops and is a stable food for large parts of the world population including Egypt. Information about phenotypic stability is useful for selection of crop varieties in a breeding program. Plant breeders encounter genotype $\times$ environment interaction $(G \times$ E) when testing varieties across a number of environments. The magnitude of the interaction or the differential genotypic responses to environments differs greatly across environments (Kaya et al., 2002).

Environmental conditions are known to have significant influence on yield of wheat. But relative magnitude of environmental, genetic, and $G \times E$ effects on grain yield is unclear, and development of a selection strategy for grain yield requires knowledge of the magnitude of the genotype and environment ( $G \times E$ ) interaction. Plant breeders carry out performance tests at different locations in different years in target areas, and data obtained from these tests are used to determine the magnitude of $G \times E$ interactions. In the presence of $G \times E$ interactions, stability parameters are estimated to determine the superiority of individual genotypes across the range of environments

Wheat production can be boosted up through cultivars having broader genetic base and better performance under various agro-climatic conditions. In wheat, genetic improvement is a slow process in nature however, the selective process of man can speed it up through appropriate management of environmental factors. Improvement gets complicated when a trait is environmentdriven and selection gets more complex (Mohammad et al., 2011.).
Multi-environment trials (METs) are used to accurately estimate and predict yield based on limited experimental data, determine yield stability and the pattern of response of genotypes across environments and provide reliable assistance for selecting the best genotypes for planting in future years and at new sites (Crossa, 1990).

The additive main effects and multiplicative interaction (AMMI) model consists of the analysis of variance for the genotype and environment main effects with the principle components analysis (PCA) of the genotypes-environments interaction. It uses the standard analysis of variance (ANOVA) procedure, where after the AMMI model separates the additive variance from the multiplicative variance (interaction), and then applies PCA to the interaction (residual) portion from the ANOVA to extract a new set of coordinate axes which account more effectively for the interaction patterns (Shafii et al. (1992)).

\section{The objectives of this study are} aimed to:

1- Estimate the stability yield and its components for twenty bread wheat genotypes across fifteen variable environments.

2- Identified the promising genotypes with high yield ability and stability.

3- Apply multivariate techniques AMMI statistical model for determination of the magnitude and pattern of GE interaction effects and performance stability of grain yield in selected wheat genotypes.

\section{MATERIALS AND METHODS}

The field experiment was carried out using 20 bread wheat genotypes which are (9 commercial cultivars (Gemmeiza 9- 
Gemmeiza11-Giza168-Sakha94-

Shandaweel 1- 1 Sids 12-Sids 13-Masr 1 and Masr2) and 11 promising lines) field experiments were conducted for three successive seasons (2009/20102010/2011- 2011/2012). The environments were represented by five locations (EL-
Gemmeiza, Sakha ,Nubaria, Sids and Shandaweel Agricultural Research Station). 20 genotypes of bread wheat were evaluated over 15 environments.

The pedigree of the studied bread wheat genotypes is presented in Table (1).

Table (1): pedigree of the studied bread wheat genotypes used in this study

\begin{tabular}{|c|c|c|}
\hline no & Genotypes & Pedigree \\
\hline 1 & Gemmeiza 9 & ALD “S” / HUAC // CMH 74A. 630 / SX CGM 4583-5GM-1GM-0GM \\
\hline 2 & Gemmeiza11 & $\begin{array}{l}\text { BOW"S"/KVZ"S"I/7C/SER182/3/GIZA168/SAKHA61 } \\
\text { GM7892-2GM-1GM-2GM-1GM-0GM }\end{array}$ \\
\hline 3 & Giza168 & $\begin{array}{l}\text { MRL/BUE/SERI } \\
\text { CM93046-8M-0Y-0M-2Y-0B }\end{array}$ \\
\hline 4 & Sakha94 & $\begin{array}{l}\text { OPATA/RAYON//KAUZ } \\
\text { CMBW90Y3180-0TOPM-3Y-010M-010M-010Y-10M015Y-0Y-0AP-0S. }\end{array}$ \\
\hline 5 & Shandaweel 1 & $\begin{array}{l}\text { SITE/MO/4/NAC/TH.AC//3*PVN/3/MIRLO/BUC } \\
\text { CMSS93B00567S-72Y-010M-010Y-010M-3Y-0M-0HTY0SH }\end{array}$ \\
\hline 6 & Sids 12 & $\begin{array}{l}\text { BUC//7C/ALD/5/MAYA74/ON//1160.147/3/BB/GLL/4/CH } \\
\text { AT"S"/6/MAYA/VUL//CMH74A.630/4*SX SD7096-4SD-1SD-1SD-0SD }\end{array}$ \\
\hline 7 & Sids 13 & $\begin{array}{l}\text { KAUZ"S" I/TSI / SNB"S" } \\
\text { ICW94-0375-4AP-2AP-030AP-0APS-3AP-0APS-050AP0AP-0SD }\end{array}$ \\
\hline 8 & Masr 1 & $\begin{array}{l}\text { OASIS I SKAUZ I/ 4*BCN /3/ 2*PASTOR CMSS00Y01881T-050M- } \\
\text { 030Y-030M-030WGY-33M-0Y0S }\end{array}$ \\
\hline 9 & Masr 2 & $\begin{array}{l}\text { SKAUZ I BAV92 } \\
\text { CMSS96M03611S-1M-010SY-010M-010SY-8M-0Y-0S }\end{array}$ \\
\hline 10 & Line 1 & $\begin{array}{l}\text { GEMMEIZA/GIZA168. } \\
\text { s-15647-8s-0sy-1s-0s. }\end{array}$ \\
\hline 11 & Line 2 & $\begin{array}{l}\text { PFAU/SERI.IB/IAMAD/3/WAXING. } \\
\text { CGSS02-Y00153S-099M-099Y-099M-46Y-0B. }\end{array}$ \\
\hline 12 & Line 3 & F6031478/MRL//CN079/3/KA-NAC/4/STAR. \\
\hline 13 & Line 4 & $\begin{array}{l}\text { KAUZI/PASTOR//BAV92/3/RAYON. } \\
\text { CMSS00M02400S-030M-030WGY-030M-13M-0Y-0NUB. }\end{array}$ \\
\hline 14 & Line 5 & $\begin{array}{l}\text { CHAM-6//GHURAB"s" /3/REGRAG-1 } \\
\text { ICW98-0042-12AP-0APS-030AP-19AP-2AP-0AP-0SD. }\end{array}$ \\
\hline 15 & Line 6 & SERI/RAYON \\
\hline 16 & Line 7 & HD2687 \\
\hline 17 & Line 8 & $\begin{array}{l}\text { SAKHA93/GEMMEIZA9. } \\
\text { S-6-1GZ-4GZ-1GZ-2GZ-OS }\end{array}$ \\
\hline 18 & Line 9 & $\begin{array}{l}\text { OTUS/3/SARA/THB/IVEE. } \\
\text { CMSS97YOO2275-5Y-010M-010Y-010M-2Y-1M-OY-OGM }\end{array}$ \\
\hline 19 & Line 10 & ALMAZ-8. ICW94-0375-2AP-1AP-030AP-0APS-6AP-0APS \\
\hline 20 & Line 11 & $\begin{array}{l}\text { BOW"s"/VEE"s"//BOW"s"/TST/3/BANI/SUEFI. } \\
\text { SD294-1SD-25D-4SD-0SD }\end{array}$ \\
\hline
\end{tabular}

The experimental layout at each environment was randomized complete 
Sh. A. El-Shamarka, et al.,

block design with three replications. Plot size $\left(4.2 \mathrm{~m}^{2}\right)$ contain six rows was $20 \mathrm{~cm}$ between rows long at $3.5 \mathrm{~m}$.

\section{Studied characters}

1- Number of spikes/ $\mathrm{m}^{-2}$ : Number of fertile tillers/ $\mathrm{m}^{-2}$ were calculated by counting all spikes per square meter

2-Number of kernels Ispikes: Average number of kernels in ten randomly chosen spikes.

3- 1000- kernel weight: A random sample of 1000- kernel were taken from each plot, hand counted and weighted in grams.

4- Grain yield (Ard/Fed.): It was calculated from the grain weight the four middle rows in each plot

\section{Statistical analysis.}

AMMI combines analysis of variance (ANOVA) and principal component analysis (PCA) into a single model with additive and multiplicative.

The eigen vector is scaled as unit vectors and are unit less, whereas, $\lambda$ has the units of yield. A convenient scaling for the multiplicative parameters is $\lambda 0.5 \mathrm{yg}$ and $\lambda 0.5 \delta \mathrm{e}$, termed the 'genotype IPCA scores' and 'environment IPCA scores' because their product gives the expected interaction value. There are at most min (G-1, E-1) axes, but usually the number of axes $\mathrm{N}$ retained in the model is smaller, producing a reduced model denoted AMMI1 or AMMI2 if retaining 1 or 2 IPCAs [Gauch and Zobel (1996)].

Genotypes with first principalcomponent axis value close to zero indicate general adaptation to environments.

A genotype is regarded as stable if its first and second correspondence analysis scores are near to zero Lopez (1990).

\section{AMMI stability value}

The AMMI Stability Value (ASV) proposed by Purchase (1997) andPurchase et al. (2000) because AMMI does not make provision for quantitative stability measure, they developed their own test based on the AMMI model's IPCA1 and IPCA2 values for each genotype. This ASV is in effect, the distance from the coordinate point to the origin in a two-dimensional scatter plot of IPCAI scores against IPCA2 scores. Because the IPCA1 score contributes more to $G \times E$ sum of squares, a weighted value is needed. This weighted value is calculated according to the relative contribution of IPCA1 to IPCA2 to the interaction sum of square.

\section{RESULTS AND DISCUSSION \\ Additive main effects and multiplicative interaction (AMMI) for grain yield character.}

The additive main effects and multiplicative interaction (AMMI) model consists of the analysis of variance for the genotype and environment main effects with the principle components analysis (PCA) of the genotypes-environments interaction. It uses the standard analysis of variance (ANOVA) procedure, where after the AMMI model separates the additive variance from the multiplicative variance (interaction), and then applies PCA to the interaction (residual) portion from the ANOVA to extract a new set of coordinate axes which account more effectively for the interaction patterns (Shafii et al. (1992)). A genotype is regarded as stable if its first and second correspondence-analysis (PCA) scores are near zero (Lopez (1990)).

The combined analysis of variance showed that there is highly significant difference for environments, genotypes and their interaction, combining analysis of variance and AMMI analysis is shown in (Table (2, 3, 4 and 5) mean squares (MS) from AMMI analysis for grain yield of 
twenty bread wheat genotypes across fifteen environments. The AMMI analysis of variance revealed that environments (E), genotypes (G) and the Genotypes $\times$ Environments interaction (GEI) mean squares were highly significant for grain yield.

Also, the AMMI analysis of variance showed that (73.79,57.47.27.45and $22.51 \%$ ) of the total sum of squares were attributable to environmental effects, $(1.72,4.96,4.01$ and $11.38 \%)$ to genotypic effects $(13.65,24.44,27.76$ and $32.4 \%)$ to GEI effects for grain yield, number of spikes $/ \mathrm{m}^{2}$, number of kernels/spike and 1000- kernel weight respectively. A large sum of squares for environments indicated that the environments were diverse, with large differences among environmental means causing most of the variations in these characters. The magnitude of the GEI sum of squares was larger than that for genotypes. indicating that there were substantial differences in genotypic response across environments. Crossa (1990) Reported that, AMMI analysis first fits the additive main effects of genotypes and environments by the usual analysis of variance and then describes the nonadditive part, genotype-environment interaction, by principal components analysis. Bradu and Gabriel (1978) and Gauch (1988) reviewed that, (AMMI) method integrates analysis of variance and principal components analysis into a unified approach. The recent results match with the previous findings. Kendal and Dogan (2015).

The genotypes $x$ environment interaction (GEI) was portioned three interaction principle components analysis axis (IPCA) for grain yield and its components. The results showed that three IPCAs were highly significant. IPCA1, IPCA2 and IPCA3 accounted for (24.5, 17.00 and $14.27 \%)$ from grain yield, (38.98, 14.63 and $10.15 \%)$ from number of spikes $/ \mathrm{m}^{2},(24.29,23.51$ and $13.65 \%)$ from number of kernel/ spike and $(30.98,22.40$ and $14.00 \%$ ) from 1000 -kernel weight, respectively. Three IPCAs represent $(55.77,63.76,61.45$ and $67.38 \%)$ of interaction variation for grain yield, number of spikes $/ \mathrm{m}^{2}$, number of kernels/ spike and 1000-kernel weight respectively.

Table (2): Combined and AMMI analysis of variance for grain yield (ardab/fed.) of twenty genotypes across fifteen environments

\begin{tabular}{|l|c|c|c|c|}
\hline Source & df & ss & $\%$ ss & MS \\
\hline Genotypes & 19 & 277 & 1.72 & $14.6^{\star *}$ \\
\hline Environments & 14 & 11892 & 73.79 & $849.4^{* *}$ \\
\hline Block & 30 & 198 & 1.23 & $6.59^{* *}$ \\
\hline Interactions & 266 & 2200 & 13.65 & $8.27^{* *}$ \\
\hline IPCA 1 & 32 & 539 & 24.5 & $16.84^{* *}$ \\
\hline IPCA 2 & 30 & 374 & 17 & $12.47^{* *}$ \\
\hline IPCA 3 & 28 & 314 & 14.27 & $11.2^{* *}$ \\
\hline Residuals & 176 & 973 & 44.23 & 5.53 \\
\hline Error & 570 & 1549 & & 2.72 \\
\hline
\end{tabular}

* and ** indicates significance at 0.05 and 0.01 level. 
Sh. A. El-Shamarka, et al.,

Table (3): Combined and AMMI analysis of variance for no. of spikes $/ \mathrm{m}^{2}$ of twenty genotypes across fifteen environments

\begin{tabular}{|l|c|c|c|c|}
\hline Source & df & SS & \% SS & MS \\
\hline Genotypes & 19 & 119689 & 4.96 & $6299^{\star *}$ \\
\hline Environments & 14 & 1381186 & 57.28 & $98656^{\star *}$ \\
\hline Block & 30 & 17520 & 5.72 & 584 \\
\hline Interactions & 266 & 589381 & 24.44 & $2216^{\star *}$ \\
\hline IPCA 1 8 & 32 & 229757 & 38.98 & $7180^{\star *}$ \\
\hline IPCA 2 & 30 & 86217 & 14.63 & $2874^{\star *}$ \\
\hline IPCA 3 & 28 & 59818 & 10.15 & $2136^{\star *}$ \\
\hline Residuals & 176 & 213589 & 36.24 & 1214 \\
\hline Error & 570 & 303355 & & 532 \\
\hline
\end{tabular}

* and ${ }^{* *}$ indicates significance at 0.05 and 0.01 level.

Table (4): Combined and AMMI analysis of variance for No. of kernels/spike of twenty genotypes across fifteen environments

\begin{tabular}{|l|c|c|c|c|}
\hline Source & df & ss & $\%$ ss & MS \\
\hline Genotypes & 19 & 2061 & 4.01 & $108.5^{\star *}$ \\
\hline Environments & 14 & 24286 & 47.27 & $1734.7^{\text {** }}$ \\
\hline Block & 30 & 1482 & 2.88 & $49.4^{\star *}$ \\
\hline Interactions & 266 & 14259 & 27.76 & $53.6^{\text {** }}$ \\
\hline IPCA 1 & 32 & 3463 & 24.29 & $108.2^{\text {** }}$ \\
\hline IPCA 2 & 30 & 3353 & 23.51 & $111.8^{\star *}$ \\
\hline IPCA 3 & 28 & 1946 & 13.65 & $69.5^{\text {** }}$ \\
\hline Residuals & 176 & 5498 & 38.56 & 31.2 \\
\hline Error & 570 & 9285 & & 16.3 \\
\hline
\end{tabular}

* and ${ }^{* *}$ indicates significance at 0.05 and 0.01 level.

Table (5): Combined and AMMI analysis of variance for 1000-Kernel weight of twenty genotypes across fifteen environments

\begin{tabular}{|l|c|c|c|c|}
\hline Source & df & ss & \% ss & MS \\
\hline Genotypes & 19 & 3866 & 20.37 & $203.49^{\star *}$ \\
\hline Environments & 14 & 4271 & 22.51 & $305.08^{* *}$ \\
\hline Block & 30 & 388 & 2.04 & 12.95 \\
\hline Interactions & 266 & 6155 & 32.4 & $23.14^{\star *}$ \\
\hline IPCA 1 & 32 & 1907 & 30.98 & $59.6^{\star *}$ \\
\hline IPCA 2 & 30 & 1379 & 22.40 & $45.97^{\star *}$ \\
\hline IPCA 3 & 28 & 862 & 14.00 & $30.8^{\star *}$ \\
\hline Residuals & 176 & 2006 & 32.53 & 11.4 \\
\hline Error & 570 & 4296 & & 7.54 \\
\hline
\end{tabular}

* and ** indicates significance at 0.05 and 0.01 level. 
The presented results are in according with the results of Mohamed (2009), Najafian et al., (2010), Farshadfar et al., (2011), Hagos and Abay (2013) and Mohamed et al., (2013).

IPCA scores of genotypes and environments displayed positive and negative values are presented in (Tables $6,7,8$ and 9). A genotype with large positive IPCA score in some environments must have large negative interaction in some other environments. Thus, these scores presented a disproportionate genotype response, which was the major source of variation for any crossover (quantitative) interaction. This disproportionate genotype response is referred to as crossover GE interaction.

Table (6): Grain yield means, interaction principle component analysis scores and AMMI stability value of twenty genotypes across fifteen environments.

\begin{tabular}{|l|c|c|c|c|c|c|}
\hline Genotype & AR/FED & IPCAg[1] & IPCAg[2] & IPCAg[3] & ASV & rank \\
\hline Gemmeiza9 & 22.7 & -0.20854 & -0.51075 & 1.44234 & 0.592614 & 6 \\
\hline Gemmeiza11 & 22.56 & -0.27373 & -0.3211 & 0.64677 & 0.508655 & 4 \\
\hline Giza168 & 22.4 & 0.1207 & 0.21224 & 0.90688 & 0.274417 & 1 \\
\hline Sakha94 & 22.98 & 0.40586 & 0.58699 & -1.54507 & 0.828664 & 7 \\
\hline Shandaweel1 & 23.03 & 0.59522 & 1.22033 & 0.35376 & 1.491662 & 13 \\
\hline Sids12 & 22.52 & 0.87272 & -1.52417 & 0.11251 & 1.976111 & 17 \\
\hline Sids13 & 22.79 & 1.35849 & 0.8949 & 0.6621 & 2.152654 & 18 \\
\hline Masr1 & 23.73 & 1.19279 & -0.63635 & 0.13781 & 1.833023 & 16 \\
\hline Masr2 & 24.07 & 0.13434 & 0.89553 & 0.02997 & 0.916219 & 9 \\
\hline G10 & 22.62 & 0.03746 & -0.52875 & -1.30475 & 0.531499 & 5 \\
\hline G11 & 23.79 & 0.32936 & -1.74369 & -0.37436 & 1.807142 & 15 \\
\hline G12 & 22.88 & 1.60238 & 0.53003 & -0.04039 & 2.369358 & 20 \\
\hline G13 & 23.39 & -0.34397 & 0.08129 & -0.46429 & 0.502342 & 3 \\
\hline G14 & 22.81 & -0.97561 & -0.25321 & 0.36984 & 1.428644 & 12 \\
\hline G15 & 22.53 & -0.60319 & -0.28016 & 0.15423 & 0.913333 & 8 \\
\hline G16 & 22.71 & -0.85084 & -0.24667 & -0.48735 & 1.250775 & 11 \\
\hline G17 & 23.11 & -1.11544 & 0.55376 & 0.46992 & 1.700251 & 14 \\
\hline G18 & 22.34 & -0.22192 & 0.29056 & -0.2691 & 0.432104 & 2 \\
\hline G19 & 22.9 & -0.54897 & 0.59698 & -1.05128 & 0.991122 & 10 \\
\hline G20 & 21.53 & -1.50709 & 0.18225 & 0.25045 & 2.179615 & 19 \\
\hline
\end{tabular}

(IPCA) interaction principle component analysis and (ASV) AMMI stability value. 
Sh. A. El-Shamarka, et al.,

Table (7): No. of spikes $/ \mathrm{m}^{2}$ mean, interaction principle component analysis scores and AMMI stability value of twenty genotypes across fifteen environments.

\begin{tabular}{|c|c|c|c|c|c|c|}
\hline Genotype & number & $\operatorname{IPCAg}[1]$ & IPCAg[2] & IPCAg[3] & ASV & rank \\
\hline Gemmeiza 9 & 383.3 & -2.89265 & -0.27564 & -3.52452 & 7.71346 & 13 \\
\hline Gemmeiza11 & 353.9 & 9.9358 & -1.26877 & -3.07084 & 26.50799 & 20 \\
\hline Giza168 & 387.3 & 3.97113 & 0.81117 & -1.84054 & 10.61358 & 16 \\
\hline Sakha94 & 391.5 & -3.92082 & 0.78061 & -0.39597 & 10.47759 & 15 \\
\hline Shandaweel1 & 375.2 & 2.73019 & -1.16486 & 2.27774 & 7.368258 & 12 \\
\hline Sids12 & 366.9 & 1.57422 & 2.36807 & 4.26649 & 4.817316 & 6 \\
\hline Sids13 & 398.6 & -8.03965 & 0.33615 & 0.40207 & 21.42725 & 19 \\
\hline Masr1 & 378.9 & -0.15771 & -5.25717 & 2.6593 & 5.273942 & 7 \\
\hline Masr2 & 399.9 & -0.96888 & 2.01741 & -2.8616 & 3.276637 & 3 \\
\hline G10 & 379.5 & 0.22352 & 5.62053 & -3.93441 & 5.652005 & 10 \\
\hline G11 & 386.3 & -1.89496 & -4.74451 & -2.38553 & 6.929001 & 11 \\
\hline G12 & 389.8 & -4.36878 & -1.94959 & 0.29812 & 11.80433 & 17 \\
\hline G13 & 400.4 & -0.45747 & -3.05921 & -2.59895 & 3.293169 & 4 \\
\hline G14 & 385.4 & 4.94678 & -0.49825 & -0.41829 & 13.19193 & 18 \\
\hline G15 & 389.1 & -2.70641 & 5.02311 & -1.58329 & 8.789076 & 14 \\
\hline G16 & 386.9 & 0.61855 & -2.23283 & 0.2918 & 2.775356 & 2 \\
\hline G17 & 369.9 & 1.61462 & 3.43924 & 2.66015 & 5.50836 & 8 \\
\hline G18 & 391.1 & 0.70433 & -1.32521 & 2.50534 & 2.297632 & 1 \\
\hline G19 & 388.3 & -1.93011 & -2.09629 & 1.81538 & 5.554271 & 9 \\
\hline G20 & 369.9 & 1.0183 & 3.47605 & 5.43756 & 4.409846 & 5 \\
\hline
\end{tabular}

(IPCA) interaction principle component analysis and (ASV) AMMI stability value. 
STABILITY ANALYSIS FOR GRAIN YIELD IN BREAD WHEAT GENOTYPES.....

Table (8): No. of kernels/ spike mean interaction principle component analysis scores and AMMI stability value of twenty genotypes across fifteen environments.

\begin{tabular}{|c|c|c|c|c|c|c|}
\hline Genotype & Number & IPCAg[1] & IPCAg[2] & $\operatorname{IPCAg[3]}$ & ASV & Rank \\
\hline Gemmeiza9 & 57.71 & -2.17257 & -0.22608 & -1.62523 & 2.255205 & 18 \\
\hline Gemmeiza11 & 58.67 & -1.07019 & 1.36899 & 0.163 & 1.759494 & 14 \\
\hline Giza168 & 57.65 & -1.63429 & 0.05508 & 0.47086 & 1.688804 & 12 \\
\hline Sakha94 & 54.47 & -1.38217 & -0.74055 & 0.53812 & 1.60817 & 11 \\
\hline Shandaweel1 & 58.63 & -1.58534 & 1.12101 & -2.01163 & 1.984333 & 16 \\
\hline Sids12 & 58.93 & -0.01668 & 1.3214 & -0.4779 & 1.321512 & 6 \\
\hline Sids13 & 57.94 & 0.01111 & -1.04113 & 0.14271 & 1.041193 & 4 \\
\hline Masr1 & 54.87 & 0.20334 & -1.32746 & -1.03448 & 1.34397 & 7 \\
\hline Masr2 & 57.72 & -0.84891 & -1.02943 & 0.83606 & 1.352196 & 8 \\
\hline G10 & 55.62 & 2.59517 & -2.97304 & -0.10882 & 4.002876 & 20 \\
\hline G11 & 55.08 & 1.00702 & 1.53649 & 1.87595 & 1.855403 & 15 \\
\hline G12 & 57.43 & 1.28379 & 0.30731 & -0.65564 & 1.361054 & 9 \\
\hline G13 & 54.68 & 0.05187 & -0.57723 & -0.74453 & 0.579711 & 2 \\
\hline G14 & 54.56 & -0.99554 & -0.41704 & 3.10666 & 1.109558 & 5 \\
\hline G15 & 55.25 & -0.90299 & -0.36019 & -0.1835 & 0.999753 & 3 \\
\hline G16 & 57.13 & 0.4398 & 1.3846 & 0.22151 & 1.457203 & 10 \\
\hline G17 & 55.32 & 1.88581 & 0.48491 & -1.17588 & 2.007133 & 17 \\
\hline G18 & 55.71 & 0.70681 & -1.59972 & -0.14297 & 1.758409 & 13 \\
\hline G19 & 55.43 & 0.2483 & -0.00887 & 0.75376 & 0.256599 & 1 \\
\hline G20 & 57.77 & 2.17567 & 2.72097 & 0.05193 & 3.528866 & 19 \\
\hline
\end{tabular}

(IPCA) interaction principle component analysis and (ASV) AMMI stability value. 
Sh. A. El-Shamarka, et al.,

Table (9): 1000-Kernel weight mean, interaction principle component analysis scores and AMMI stability value of twenty genotypes across fifteen environments.

\begin{tabular}{|l|c|c|c|c|c|c|}
\hline Genotype & Gram & IPCAg[1] & IPCAg[2] & IPCAg[3] & ASV & Rank \\
\hline Gemmeiza 9 & 48.58 & -1.019 & 0.463 & -0.727 & 1.66 & 12 \\
\hline Gemmeiza11 & 52.2 & 1.687 & 2.419 & 0.671 & 3.34 & 19 \\
\hline Giza168 & 46.65 & 0.152 & -1.055 & -1.563 & 1.50 & 7 \\
\hline Sakha94 & 46.35 & 0.389 & 1.495 & 0.560 & 1.53 & 8 \\
\hline Shandaweel1 & 45.92 & -0.175 & -0.142 & 0.431 & 1.61 & 11 \\
\hline Sids12 & 49.53 & -0.754 & 0.135 & -0.609 & 1.26 & 4 \\
\hline Sids13 & 43.48 & -0.527 & -0.078 & 1.589 & 1.33 & 5 \\
\hline Masr1 & 48.32 & -0.031 & 1.430 & -0.431 & 1.48 & 6 \\
\hline Masr2 & 45.2 & -0.856 & -0.250 & 0.963 & 1.20 & 2 \\
\hline G10 & 49.31 & 0.580 & 0.298 & -0.690 & 2.02 & 16 \\
\hline G11 & 48.8 & 1.568 & 0.109 & -0.633 & 2.37 & 17 \\
\hline G12 & 47.19 & 0.804 & -0.387 & 0.055 & 1.07 & 1 \\
\hline G13 & 48.14 & -0.977 & 0.268 & 0.091 & 1.21 & 3 \\
\hline G14 & 48.63 & -0.305 & -2.112 & 2.023 & 1.78 & 14 \\
\hline G15 & 48.32 & -1.394 & 0.275 & 1.021 & 1.89 & 15 \\
\hline G16 & 46.4 & 0.415 & -1.258 & -0.471 & 1.53 & 9 \\
\hline G17 & 51.27 & 2.646 & -1.500 & -0.243 & 4.48 & 20 \\
\hline G18 & 46.24 & 0.916 & -0.159 & 0.089 & 1.68 & 13 \\
\hline G19 & 46.24 & -1.902 & -0.734 & -1.541 & 2.93 & 18 \\
\hline G20 & 50.4 & -1.217 & 0.786 & -0.586 & 1.53 & 10 \\
\hline
\end{tabular}

(IPCA) interaction principle component analysis and (ASV) AMMI stability value

The AMMI stability value measure was proposed by Purchase, (1997) and Purchase et al., (2000). ASV is the distance from zero in a two-dimensional scatter gam of IPCA 1 score against IPCA 2. A genotype with least ASV is the most stable, in respect to grain yield as given in
Table (6) and illustrated in Figure (1), the most stable genotypes were Giza168, G18, G13, Gemmeiza11and G10 with high yield potential, where genotypes G12, G20, Sids 13 and Sids12 unstable and more responsive to the environmental changes. 


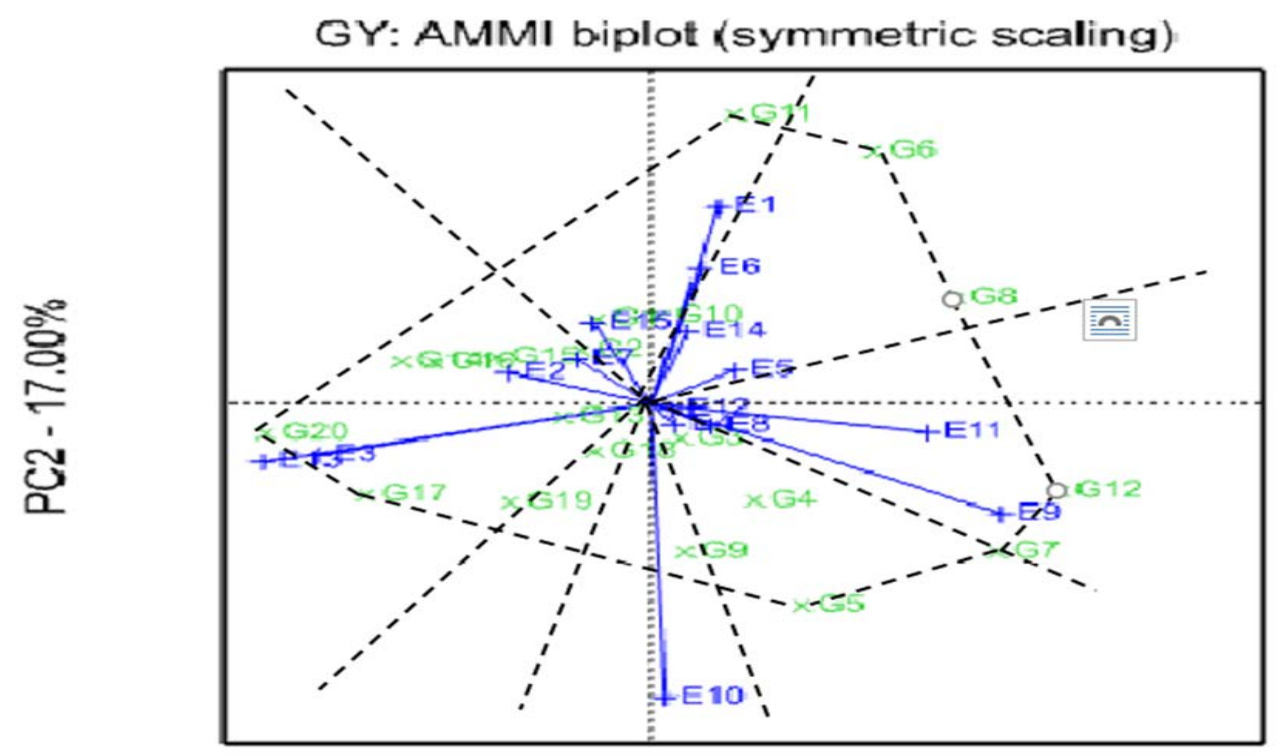

PC1 - 24.49\%

Figure 1: Additive mean multiplicative interaction (AMMI) scatter plot for grin yield (GY), + Environment sign and $\times$ genotype sign.

\begin{tabular}{|c|c|c|c|c|c|c|c|}
\hline code & genotypes & code & genotypes & code & environment & code & environment \\
\hline G1 & Gemmeiza 9 & G11 & Line 2 & E1 & Sakha year 9/10 & E11 & Sakha year 11/12 \\
G2 & Gemmeiza11 & G12 & Line 3 & E2 & Gem.year 9/10 & E12 & Gem.year 11/12 \\
G3 & Giza168 & G13 & Line 4 & E3 & Nubariayear 9/10 & E13 & Nubariayear 11/12 \\
G4 & Sakha94 & G14 & Line 5 & E4 & Sidsyear 9/10 & E14 & Sidsyear 11/12 \\
G5 & Shandaweel 1 & G15 & Line 6 & E5 & Shandaweel year 9/10 & E15 & Shandaweel year 11/12 \\
G6 & Sids 12 & G16 & Line 7 & E6 & Sakha year10/11 & & \\
G7 & Sids 13 & G17 & Line 8 & E7 & Gem.year 10/11 & & \\
G8 & Masr 1 & G18 & Line 9 & E8 & Nubariayear 10/11 & & \\
G9 & Masr 2 & G19 & Line 10 & E9 & Sidsyear 10/11 & & \\
G10 & Line 1 & G20 & Line 11 & E10 & Shandaweel year 10/11 & & \\
\hline
\end{tabular}

The best genotypes with respect to E5 and E14 were Sids12 and Masr1. For E13, $E 3, E 2$ and $E 7$ as well as $G 20$ and $G 17$. For $E 6$, E1 and E15 were G11. for E4 was Sids13and shandaweel1 fore E9, E11, E8 and E12 were G12; also show that E1, E9 and E13 were the most discriminative environments as indicated by the longest distance between its mark and the origin and accounted the most part of $G \times E$ interaction.

Concerning number of spikes $/ \mathrm{m}^{2}$ Table (7) and Figure (2) the most stable genotypes were G18, G16, Masr2, G13 and
G20 with high yield potential, where genotypes Gemmeiza11, Sids13, and G14 unstable and more responsive to the environmental changes.

The best genotypes with respect to E15, E10, E8, E3, E9, E5, E13, E4 and E12 were Gemmeiza11. for E6, E2, E1, E7 and E11 were Sids13.; also show that E1 and E6 were the most discriminative environments as indicated by the longest distance between its mark and the origin and accounted the most part of $G \times E$ interaction. 


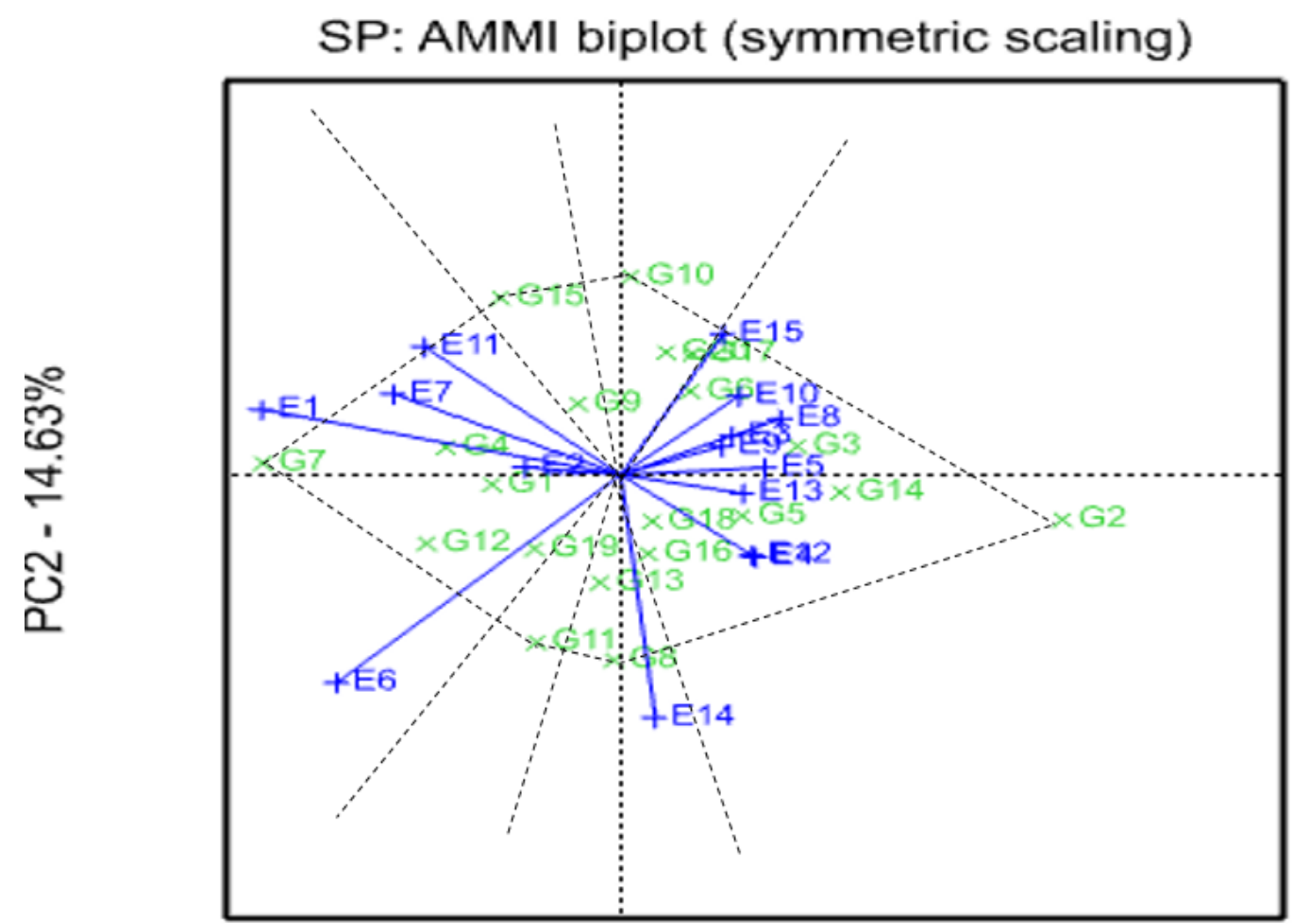

\section{PC1 - 38.98\%}

Figure 2: Additive mean multiplicative interaction (AMMI) scatter plot for no.of spikes $/ \mathrm{m}^{2}(\mathrm{SP})$, + Environment sign and $\times$ genotype sign.

With regarded to number of kernels/ spike Table (8) and Figure (3) the most stable genotypes were G19, G13, G15, Sids13and G14 with high yield potential, while the genotypes G10, G20, and Gemmeiza 9 unstable and more responsive to the environmental changes.

The best genotypes with respect to E7, E12, E2 and E8 were G20. for E1, E13, E3, $E 10$ and E11 as well as G10.for E5, E15 and E4 were G1. for E9, E6 and E14 were Shandaweel 1 the results show that E14, E15, E5 and E4 were the most discriminative environments as indicated by the longest distance between its mark and the origin and accounted the most part of $G \times E$ interaction.
For 1000-kernel weight Table (9) and Figure (4) the most stable genotypes were G12, Masr2, G13, Sids12and Sids13 with high yield potential, where genotypes G17, Gemmeiza11, and G19 unstable and more responsive to the environmental changes. Gemmeiza11 was the best genotypes at E10, E15, E5, E7, E14 andE4, while G17 the best genotypes at E1 and E6. G19 the best genotypes at E3, E9, and E13.

The most discriminative environments as indicated by the longest distance between its mark and the origin and accounted the most part of $G \times E$ interaction. 


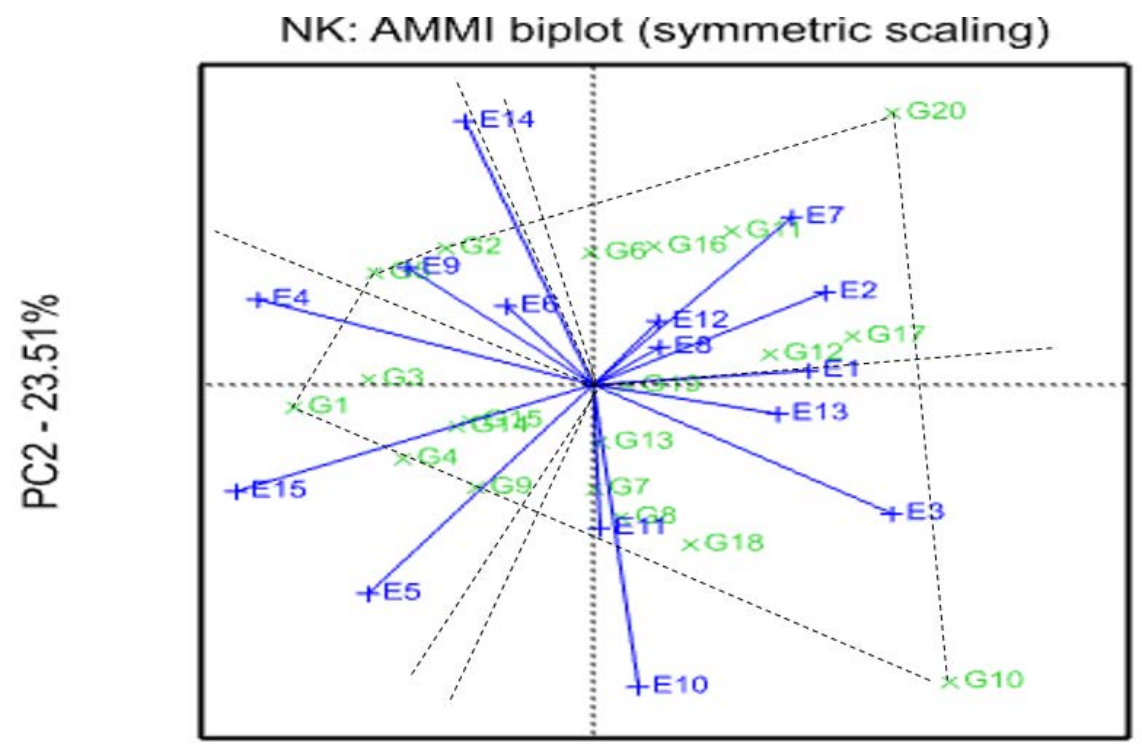

PC1 - 24.28\%

Figure 3: Additive mean multiplicative interaction (AMMI) scatter plot for No. of kernel/spike (NK), + Environment sign and $\times$ genotype sign.

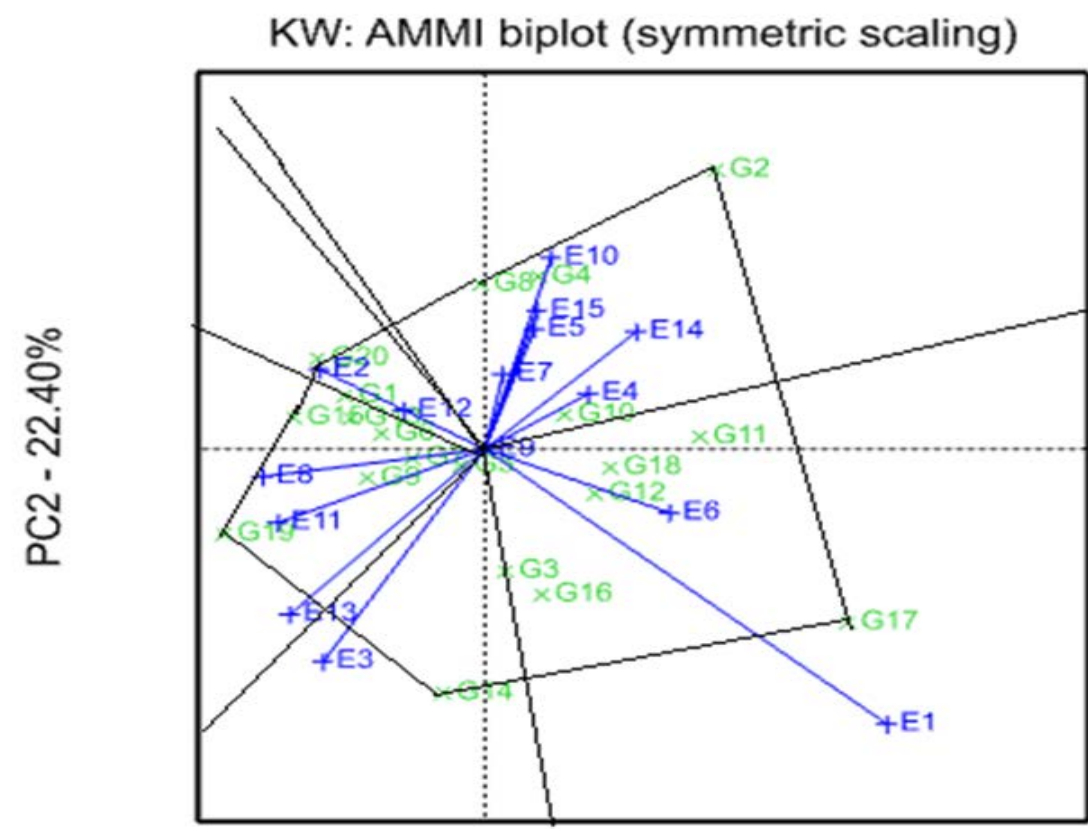

PC1 - 30.99\%

\begin{tabular}{|ll|}
$\times$ & Genotype scores \\
+ & $\begin{array}{l}\text { Environment scores } \\
\text { Vectors }\end{array}$ \\
\hline
\end{tabular}

Figure 4: Additive mean multiplicative interaction (AMMI) scatter plot for 1000-Kernel weight $(\mathrm{KW}),+$ Environment sign and $\times$ genotype sign. 


\section{Conclusion}

1- The results Indicated that genotypes the most stable genotypes were Giza168, G18, G13, Gemmeiza11and G10 with high yield potential. The best genotypes with respect to E5 and E14 were Sids12 and Masr1. for E13, E3, E2 and $E 7$ as well as $G 20$ and $G$ 17.for E6, E1 andE15 were G11. for E4 was Sids13and shandaweel1 fore E9, E11, E8 and E12 were G12; also show that E1, E9 and E13 were the most discriminative environments for grain yield.

2- The most stable genotypes were $\mathbf{G 1 8}$, G16, Masr2, G13and G20 with high yield potential and the environments number (E15, E10, E8, E3, E9, E5, E13, $E 4$ and E12) were Gemmeiza11. For E6, E2, E1, E7 and E11 were Sids13.; also show that E1 and E6 were the most discriminative environments for number of spikes $/ \mathrm{m}^{2}$.

3- With regarded to number of kernels/ spike the most stable genotypes were G19, G13, G15, Sids13and G14 with high yield potential, where genotypes G10, G20.The best genotypes with respect to E7, E12, E2 and E8 were G20. for E1, E13, E3, E10 and E11 as well as G10.for E5, E15 andE4 were G1. for E9, E6 and E14 were Shandaweel1; also show that E14, E15, E5 and E4 were the most discriminative environments.

4- For 1000-kernel the most stable genotypes were G12, Masr2, G13, Sids12and Sids13 with high yield potential, where genotypes G17, Gemmeiza11, and G19 unstable and more responsive to the environmental changes. Gemmeiza11 was the best genotypes at E10, E15, E5, E7, E14 andE4, while $G 17$ the best genotypes at E1 and E6. G19 the best genotypes at E3, E9, and E13.

\section{REFERENCES}

Crossa, J. (1990). Statistical analyses of multilocation trials. Advances in Agronomy 44: 55-85

Bradu, D. and K.R. Gabriel (1978). The biplot as a diagnostic tool for models of twoway tables. Technometrics, 20(1): 47-68.

Farshadfar, E., N. Mahmodi and A. Yaghotipoor (2011). AMMI stability value and simultaneous estimation of stability and yield stability in bread wheat (Triticum aestivum L.). AJCS 5(13): 1837-1844.

Gabriel, K. R. (1971). The biplot graphic of matrices with application to principle component analysis. Biometrics 58: 453-467.

Gauch, H. G. (1988). Model selection and validation for yield trials with interaction. Biometrics, 44: 705-715.

Gauch, H. G. and R. W. Zobel (1996). AMMI analysis of yield trials. In M. S. Kang and H. G. Gauch, Jr (Eds). Genotypeenvironment interaction. Boea Raton, CRC press. pp 85-122.

Hagos, H.G. and F. Abay (2013). AMMI and GGE biplot analysis of bread wheat genotypes in the northern part of Ethiopia. J. of Plant Breeding and Gen. 1(1): 12-18.

Kang, M.S. (2002). Genotype-environment interaction: progress and prospects. Quantitative genetics, genomics and plant breeding. CAB International, E.d. M.S. Kang, 221-243.

Kaya, Y., M. Akçura and S. Taner (2002a). GGE-biplot analysis of multienvironment yield trials in bread wheat. Turkish Journal of Agriculture and Forestry, 30(5): 325-337.

Kaya, N., C. Paita and S. Taner (2002b). Additive main effects and multiplicative interaction analysis of yield performance in bread wheat genotypes across environment. Turk. J. Agric. 26: 275-279. 
Kendal, E., Y. Doğan (2015). stability of a candidate and cultivars (hordeum vulgare I) by GGE biplot analysis of multi-environment yield trial in spring barley. Agriculture \& Forestry, 61(4): 307-318

Lopez, J. (1990). Estudio de la base geneeyica del contenidoentaninos condensadaosen la semila de las habes (Vicia faba L.). Doctoral dissertation, university of Cardoba, Spain.

Mohamed, M. I. (2009). Genotype × environment interaction in bread wheat in Northern Sudan using AMMI analysis. Am-Euras.

Mohamed, N. E. M., A. A. Said and K. A. Amein (2013). Additive main effects and multiplicative interaction (AMMI) and GGE biplot analysis of genotype $\times$ environment interaction for grain yield in bread wheat (Triticum aestivum L.). Afr.J.Agric.Res.8(42):5197-5203.

Mohammad, F., O.S. Abdalla, S. Rajaram, A. Yaljarouka, N.U. Khan, A.Z. Khan, S.K. Khalil, I.H. Khalil, I. Ahmad and S.A. Jadoon (2011). Additive main effect and multiplicative analysis of synthetic-derived wheat under varying moisture regimes. Pak. J. Bot. 43 (2): 1205-1210

Najafian, G., A.K. Kaffashi and A. JaferNezahd (2010). Analysis of grain yield stability in hexaploid wheat genotypes grown in temperate regions of Iran using additive main effects and multiplicative interaction. J. Agr. Sci. Tech.12: 213-222.

Purchase, J. L. (1997). Parametric analysis to describe Genotype x Environment interaction and yield stability in winter wheat. Ph.D. Thesis, Department of Agronomy, Faculty of the Free State, Bolemfontein, South Africa.

Purchase, J. L., H. Hatting and C. S. Van Deventer (2000). Genotype X Environment interaction of winter wheat (Triticum aestivumL.) in South Africa. II. Stability analysis of yield performance. S. Afr. J. Plant Soil 17:101-107.

Shafii, B., K. A. Mahler, W. J. Price and D. L. Auld (1992). Genotype X Environment interaction effects on winter rapeseed yield and oil content. Crop Science, 32: 922-927. 
تحليل الثبات لمحصول الحبوب في بعض التراكيب الوراثية لقمح الخبز

شعبان احمد الثمارقة(1)، محروس عبدالغنى ابوشريف(2)، ابراهيم الحسينى درويش(1)، هند حسن الفقى (2)

(1) قسم المحاصيل-كلية الززراعة-شبين الكوم-جامعة المنوفية

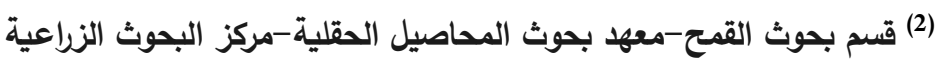

الملغص العربى

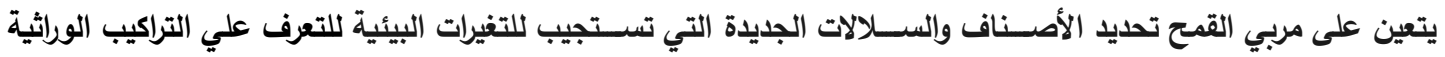

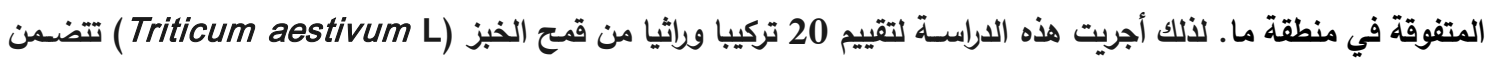

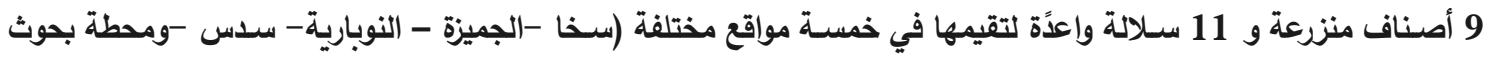

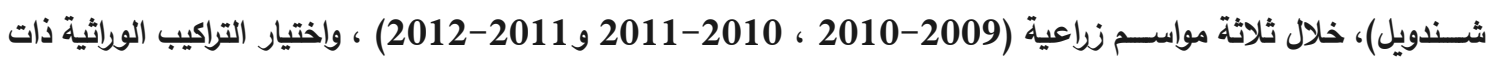

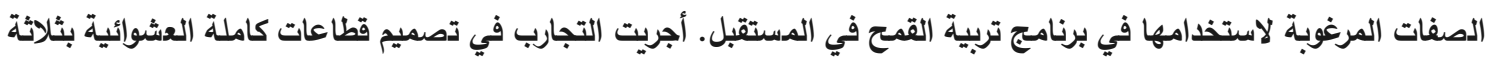

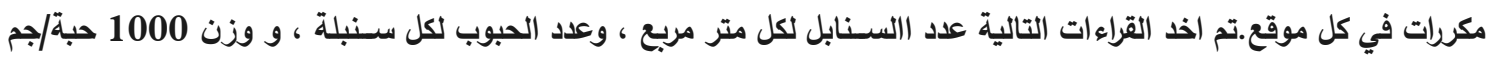

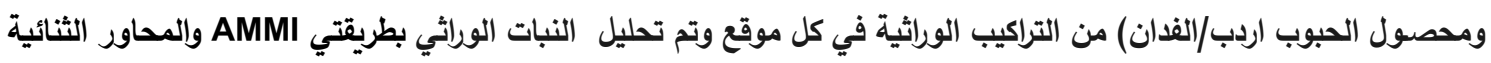

للتفاعل بين البيئة والتركيب الوراثي (GE- Biplot)

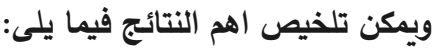

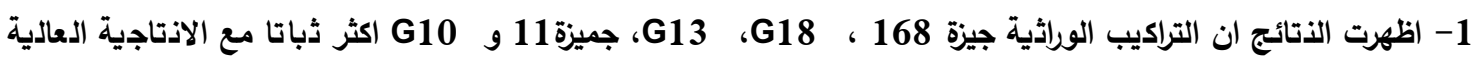

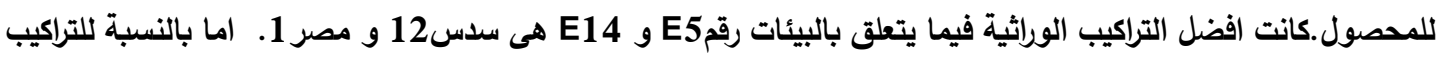

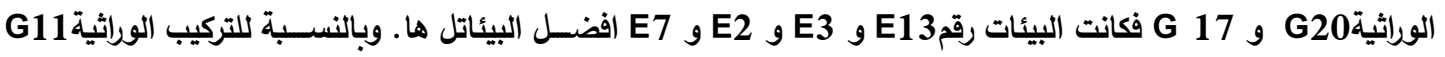

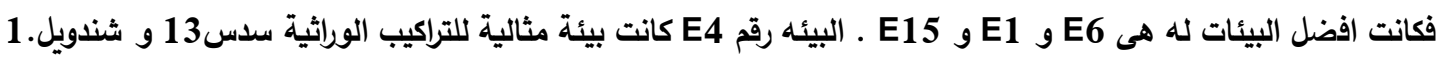

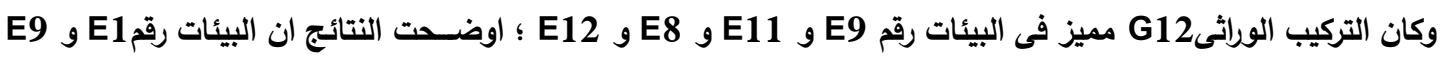

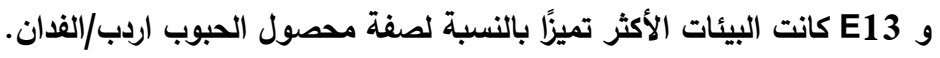

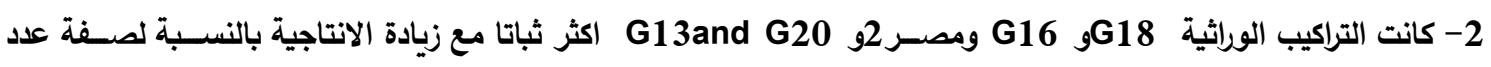

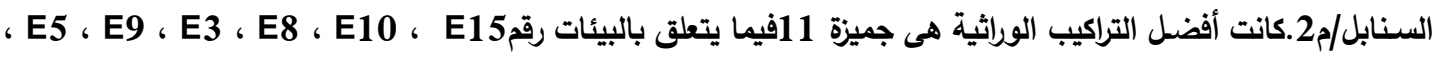

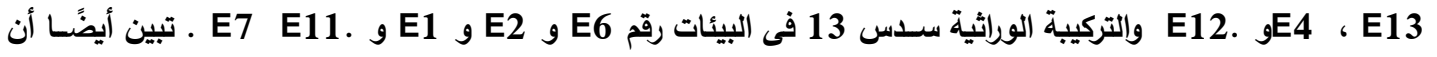

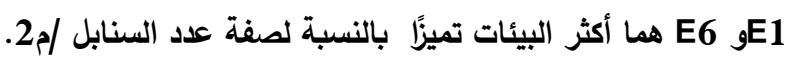

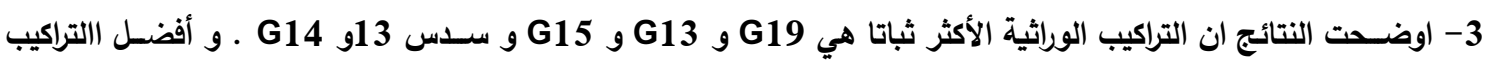

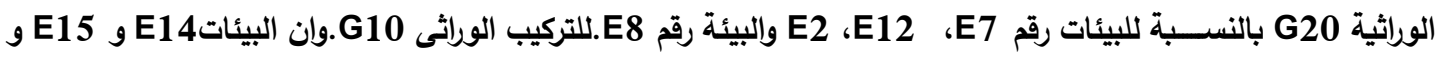

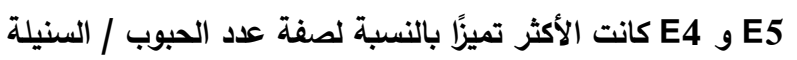

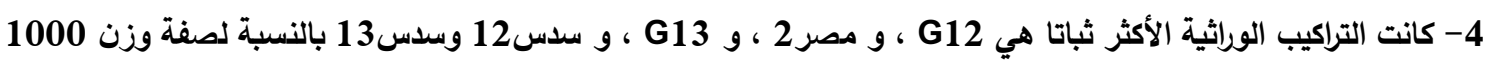

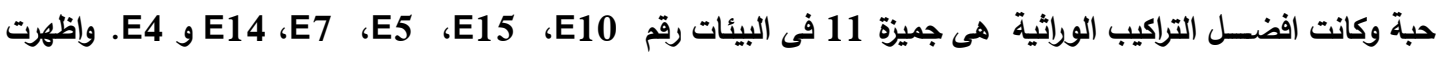

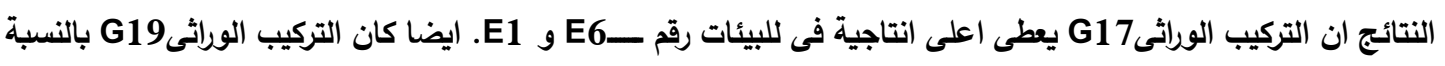

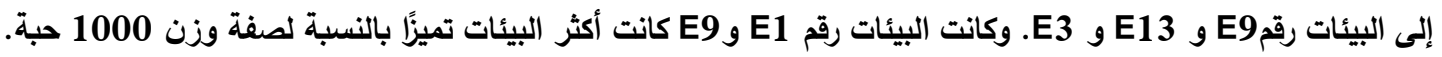

أسماء السـادة المحكمبن أ.د/ على عبالمقصود الحصرى كلية النزاعة- مشتهر- بنها ، أ.د/ حسان عبدالجيد دوام كلية الززاعة- جامعة المنوفية 